\title{
Data set of submerged sand deposits organised in an interoperable spatial data infrastructure (Western Sardinia, Mediterranean Sea)
}

\author{
Walter Brambilla ${ }^{1}$, Alessandro Conforti ${ }^{1}$, Simone Simeone $^{1}$, Paola Carrara $^{2}$, Simone Lanucara ${ }^{2}$, and \\ Giovanni De Falco ${ }^{1}$ \\ ${ }^{1}$ Istituto per lo studio degli impatti Antropici e Sostenibilità in ambiente marino del CNR, Oristano, Italy \\ ${ }^{2}$ Istituto per il Rilevamento Elettromagnetico dell'Ambiente CNR, Milan, Italy \\ Correspondence: Walter Brambilla (walter.brambilla@ias.cnr.it)
}

Received: 19 October 2018 - Discussion started: 20 December 2018

Revised: 20 March 2019 - Accepted: 25 March 2019 - Published: 23 April 2019

\begin{abstract}
The expected global sea level rise by the year 2100 will determine adaptation of the whole coastal system and the land retreat of the shoreline. Future scenarios coupled with the improvement of mining technologies will favour increased exploitation of sand deposits for nourishment, especially for urban beaches and sandy coasts with lowlands behind them. The objective of the work is to provide useful tools to support planning in the management of sand deposits located on the continental shelf of Western Sardinia (western Mediterranean Sea). The work has been realised through the integration of data and information collected during several projects. Available data consist of morpho-bathymetric data (multibeam) associated with morphoacoustic (backscatter) data, collected in the depth range -25 to $-700 \mathrm{~m}$. Extensive coverage of high-resolution seismic profiles (Chirp $3.5 \mathrm{kHz}$ ) has been acquired along the continental shelf. Also, surface sediment samples (Van Veen grab and box corer) and vibrocorers have been collected. These data allow mapping of the submerged sand deposits with the determination of their thickness and volume and their sedimentological characteristics. Furthermore, it is possible to map the seabed geomorphological features of the continental shelf of Western Sardinia. All the available data (https://doi.org/10.1594/PANGAEA.895430) have been integrated and organised in a geodatabase implemented through a GIS and the software suite Geoinformation Enabling ToolkIT StarterKit ${ }^{\circledR}$ (GET-IT), developed by researchers of the Italian National Research Council for RITMARE project. GET-IT facilitates the creation of distributed nodes of an interoperable spatial data infrastructure (SDI) and enables unskilled researchers from various scientific domains to create their own Open Geospatial Consortium (OGC) standard services for distributing geospatial data, observations and metadata of sensors and data sets.

Data distribution through standard services follows the guidelines of the European Directive INSPIRE (DIRECTIVE 2007/2/EC); in particular, standard metadata describe each map level, containing identifiers such as data type, origin, property, quality, processing processes to foster data searching and quality assessment.
\end{abstract}

\section{Introduction}

The sediments used for coastal defence from erosion and flooding have assumed a strategic value in the last decades and they will be even more important in the future considering the expected scenarios of sea level rise.

Several studies have predicted that the global sea level will rise at 2100 in a range between 530 and $1400 \mathrm{~mm}$ (Church et al., 2013; Horton et al., 2014; Kopp et al., 2016; Mengel et al., 2016; Rahmstorf, 2007). The predicted sea level rise can determine an adaptation of the whole coastal systems in terms of shoreline retreat and growing risk of coastal flooding (Antonioli et al., 2017). In order to counteract the coastal flooding due to sea level rise, an increase in the exploitation of submerged sand deposits (SSDs) could be necessary, as a 
strategic resource with which to carry out coastal protection programmes.

The management of coastal erosion has received greater attention during the past decade (Jimenez et al., 2011).

Several projects funded by the European Commission (EUROSION, Conscience, Micore) were launched to achieve the strategic objective of developing guidelines on sustainable management of coastal erosion in Europe (Marchand et al., 2011). A basic concept of coastal erosion management is the "favourable sediment status", defined by the EUROSION project as a situation in which the availability of coastal sediments supports the objective of promoting coastal resilience in general and of preserving dynamic coastlines in particular (Marchand et al., 2011; Gault et al., 2011; Sànchez-Arcilla et al., 2011).

The EUROSION concepts were applied to the Conscience Project, which also includes the sediment reservoirs on the sediment cell that can act as a source of sediment (Van Rijn, 2010). These aspects are also discussed in the Micore Project, which stressed the application of nourishment projects to contrast climate change effects, in particular extreme storms and the sea level rise (Ciavola et al., 2011).

Within this framework, the strategic sediment reservoirs are an essential component and they can be used as an intervention measure as a source of nourishment.

The exploitation of SSDs can be addressed to (i) beach nourishment, especially along urban beaches and sandy coasts facing lowlands, and (ii) the reconstruction and recovery of the foredune.

Extensive interventions of beach nourishment based on the massive use of sediments have been carried out in northern and southern Europe and across the United States to tackle problems of erosion (Finkl and Walker, 2005; Radermacher et al., 2017; Pranzini, 2018; van Egmond et al., 2018). In some cases, these interventions were realised using tens of millions of cubic metres of sand (Richards and Nicholls, 2009). Due to the large volumes of sand required for beach nourishment projects, dredging from the offshore sediment reservoirs is the preferred method of sediment supply. Because easily accessible and previously known deposits have been exploited, apparent sand reserves are a dwindling resource that becomes more precious over time (Khalil and Finkl, 2011). In fact, the marine sand deposits on the continental shelves are a non-renewable resource. For these reasons, some countries have implemented mapping and characterisation of SSDs in order to plan their future exploitations: the characterisation of SSDs, in terms of areal distribution, thickness, grain size, chemical and mineralogical composition, represents the first step in planning the exploitation of reservoirs over the coming decades, considering the predicted sea level rise scenarios.

Along the Mediterranean Sea, and in particular along the Italian coastline, the characterisation of SSDs is one of the main objectives of the Italian Ministry of Environment, Land and Sea, which in 2017 issued national guidelines to prevent and protect coasts from erosion and the effects of climate change (EUROSION, 2014; MATTM-Regioni, 2018).

There are several examples all around the world on the utilisation of SSDs for nourishment projects (Finkl and Khalil, 2005). In Italy, in the Emilia-Romagna region, a geodatabase named IN_SAND was developed which helps the managers to plan the SSD exploitation (Correggiari et al., 2012, 2016). It is also known that the dredging operation can negatively affect the marine ecosystems and in particular the sessile benthic communities (Rogers, 1990; Desprez, 2000; Erftemeijeret al., 2012; Fraser et al., 2017). For this reason, accurate procedures that aimed to minimise the impact of nourishment operations (including dredging) are adopted by several countries and must be required when a nourishment project is developed (Finkl and Khalil, 2005; Radermacher et al., 2017). Along the Mediterranean Sea, this operation can affect the Posidonia oceanica meadows. In Italy, for this reason, ISPRA and CNR developed the ENV_SAND database (Grande et al., 2015), which aimed to collect the data acquired during the monitoring programme of a nourishment project, including the dredging of the SSDs (Nicoletti et al., 2018; MATTM-Regioni, 2018). The introduction of these geodatabases provides instruments that could be very helpful in the management of SSDs, not only in terms of sand volume but to (i) support the environmental impact assessments, (ii) monitor the marine environmental conditions during the activities and (iii) manage the impact of dredging and nourishment activities on marine ecosystems (Erftemeijeret al., 2012; Fraser et al., 2017; Nicoletti et al., 2018; MATTMRegioni, 2018).

In this work, we present a large data set that was collected and organised to support the management of SSDs located along the continental shelf of Western Sardinia (Mediterranean Sea).

The data set results from the integration of geomorphological, seismic and sedimentological data collected in several projects, along the Western Sardinian (Italy) margin. A set of maps showing information on thickness, volume and sedimentological features of SSDs has been produced. They represent fundamental knowledge that supports planning and management actions of maritime space and resources. The data set has been organised following the indication of InSand guidelines (Correggiari et al., 2016) issued by the Italian Ministry of Environment, Land and Sea. Furthermore, all data have been organised and are managed by means of the software suite Geoinformation Enabling Toolkit StarterKit ${ }^{\circledR}$ (GET-IT), developed by the Italian National Research Council, which facilitates the creation of distributed nodes of an interoperable spatial data infrastructure.

\section{Regional setting}

The sand reservoirs are located along the shelf of the central sector of the Western Sardinian margin (western Mediter- 


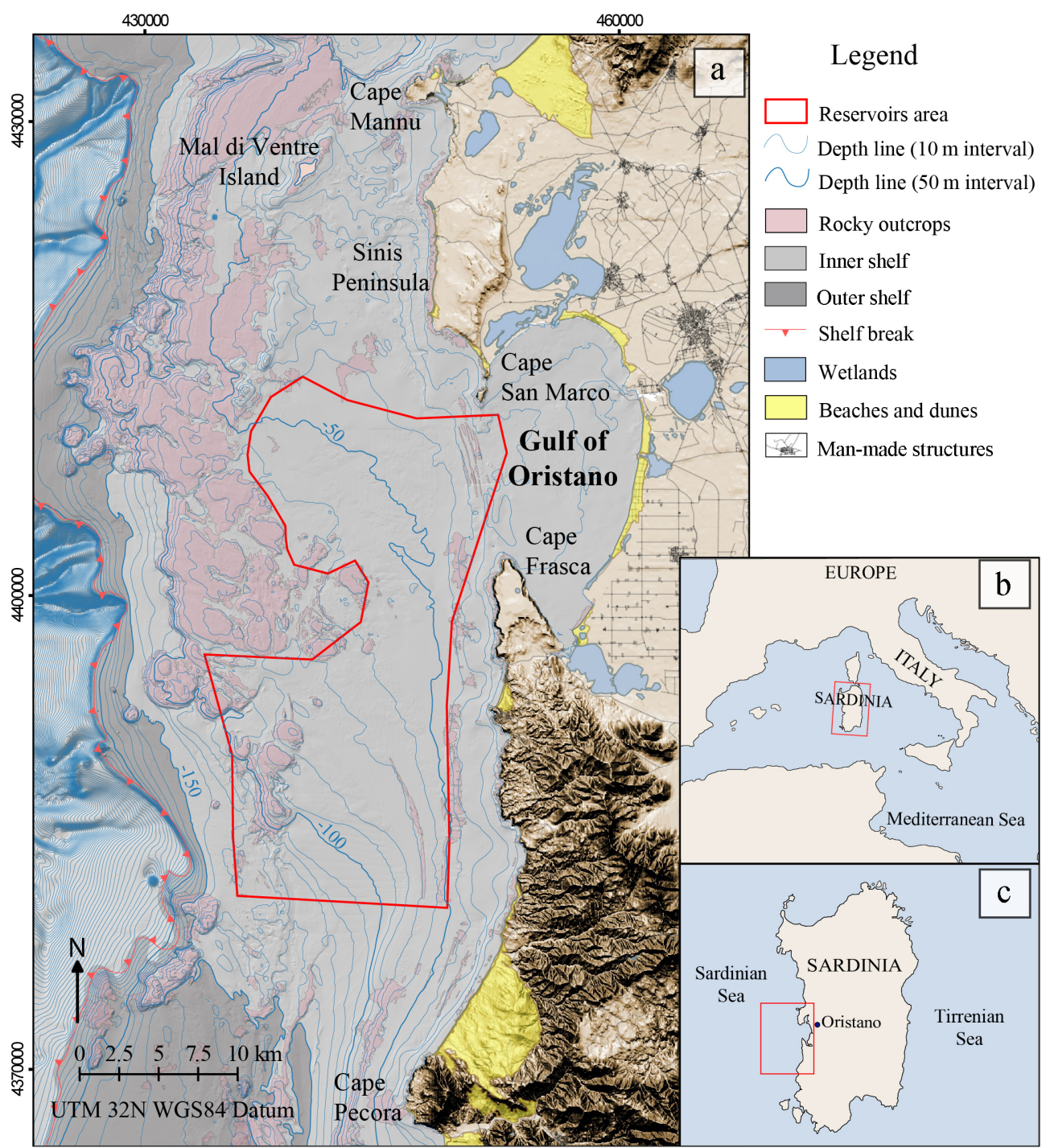

Figure 1. (a) Location of the study area and schematic geomorphological map; (b) geographic surroundings of the study area; (c) regional map.

ranean Sea, Fig. 1), a passive-type margin that has been tectonically stable since the late Quaternary (Lambeck et al., 2011). The morphology of the margin is mainly controlled by tectonic features and is characterised by a wide amphitheatre facing the Gulf of Oristano, which shows a smooth transition between the $25 \mathrm{~km}$ wide continental shelf and the deep basin. The Oristano amphitheatre is bordered to the north and south by a continental shelf which is twice as wide (Sage et al., 2005; De Falco et al., 2015). Along the study area, the Paleozoic-early Miocene acoustic basement rises and outcrops (Fig. 1). Eastwards, a small basin was filled by the Pliocene sequence and westwards the basement is depressed and overlaid by the Pliocene and Quaternary sequence (Lecca, 2000; De Falco et al., 2015). South of the study area, the acoustic basement is tectonically downthrown and the resulting structural depression is filled by the
Miocene sequence, truncated at the top by the Messinian erosional surface and covered by the Pliocene sequence (Lecca et al., 1986).

The continental shelf is sediment-starved, with limited land-to-sea sedimentary run-off. The transgressive deposits associated with the last sea level rise are characterised by siliciclastic sands and calcareous bioclastic sands (Carboni et al., 1989; De Falco et al., 2008, 2010, 2015, 2017) along the inner shelf as well as clays and calcareous mud along the outer shelf (Carboni et al., 1989).

Along the wave-dominated and starved shelves, transgressive deposits mainly derive from the reworking of sediment deposited during either low-stand conditions of the sea level or the production and reworking of intrabasinal biogenic carbonate sediments (Emery, 1968; De Falco et al., 2015). 
The western coast of Sardinia is characterised by a low degree of urbanisation and extended pristine coastal sectors. The sandy shores of this sector are extremely varied and include long linear beaches, wide large transgressive dune fields, embayed beaches and barrier-lagoon systems (Simeone and De Falco, 2012; De Falco et al., 2014; Simeone et al., 2014, 2016). Beach sediments are heterogeneous in composition (terrigenous vs. biogenic carbonate) and grain size (De Falco et al., 2014). Starting from the south of the studied area (Fig. 1) wide linear multibarred beaches, with large parabolic dunes, characterise the open coastline between Cape Pecora and Cape Frasca, with a few embayed beaches. Foreshore sediments are mainly terrigenous and are characterised by coarse grain sizes, ranging from slight gravelly to gravelly sands (Arisci et al., 2003; De Falco et al., 2014; PueyoAnchuela et al., 2017). In the Gulf of Oristano, the morphology is characterised by the presence of a foredune and the absence of bars in the shoreface. The sediment composition is terrigenous, with the exception of the northern sector of the gulf, where sediments are mixed (Tigny et al., 2007; Simeone and De Falco, 2012; De Falco et al., 2014). Grain sizes range from fine sand to gravelly sand. The coastal sector located between Cape Mannu and Cape San Marco is characterised by wide mixed bioclastic and siliciclastic beaches (in the proximity of Capo Mannu), coarse siliciclastic beaches (Sinis Peninsula) and, in the proximity of San Marco, embayed and semi-embayed mixed bioclastic terrigenous beaches. Grain sizes vary from medium-tocoarse sand in the proximity of Cape Mannu, from coarse sand to very fine gravel along Sinis Peninsula and from fine sand to very coarse sand in the proximity of Cape San Marco (Simeone et al., 2018; De Falco et al., 2017, 2014, 2003).

\section{Methods}

The thicknesses and volumes of the submerged sand deposits and their sedimentological characterisation were obtained through integration and analysis of available data collected during several projects (MAGIC, RITMARE, SIGLA). Geophysical data were collected during several oceanographic cruises using the CNR research vessels $\mathrm{R} / \mathrm{V}$ Urania, $\mathrm{R} / \mathrm{V}$ Minerva Uno, R/V Thetis. The sector where the SSD is located is shown in Fig. 1. The organisation of the GIS of SSDs was based on the GIS architecture developed by Correggiari et al. (2016) for the SSDs of the Emilia-Romagna region (InSAND project).

To ease processing and data sharing among researchers, all available data were integrated and organised in a geodatabase implemented through a GIS and the software suite Geoinformation Enabling Toolkit StarterKit ${ }^{\circledR}$ (GET-IT) (Fugazza et al., 2014; Pavesi et al., 2016; Lanucara et al., 2017) developed by researchers of the Italian National Research Council for RITMARE project. GET-IT facilitates the creation of distributed nodes of an interoperable SDI and enables unskilled researchers from various scientific domains, such as geologists, oceanographers and biologists, to create their own Open Geospatial Consortium (OGC) standard services for distributing geospatial data, observations and metadata of sensors and data sets in an interoperable way. Interoperable SDI approach prevents useless and error-prone duplication of data sources, which are made available (for visualisation, access and, if allowed, download) through standard web services, reachable from an OGC standard web authorised client. The following subsections illustrate methods adopted for different data collected in the work.

\subsection{Multibeam echosounder data}

Multibeam echosounder (MBES) data were collected along $2400 \mathrm{~km}^{2}$ of the western continental shelf of Sardinia (Fig. 2) in order to create a detailed bathymetric map, thus providing a digital terrain model (DTM) of the seabed along the middle-outer continental shelf and upper slope sectors. Different MBES devices were used. They included a Reson SeaBat 7125 operating at a sonar frequency of $200-400 \mathrm{kHz}$, Reson SeaBat $8111(100 \mathrm{kHz})$, Kongsberg EM710 (100 kHz) (see De Falco et al., 2010, 2015, 2017 for a detailed description of MBES and backscatter data acquisition and processing). MBES data allowed the production of the seabed DTM at a resolution of $2.5 \mathrm{~m}$ (Fig. 3a). Furthermore, a backscatter map (Fig. 3b) of relative backscatter intensity values was realised to recognise the morphological features of the seabed. Rocky outcrops and superficial limits of sedimentary bodies were mapped through the interpretation of the DTM with $2.5 \mathrm{~m}$ cell size and backscatter map. MBES data were processed using the software Reson PDS-2000 and DTMs were produced and analysed by using the Golden Software Surfer and Global Mapper software.

\subsection{Seismic data}

More than $100 \mathrm{~km}$ of very high-resolution seismic data were collected along the study area (Fig. 2) using a Data Sonic Chirp II operating at $3.5 \mathrm{kHz}(2.5-7 \mathrm{kHz})$. The base of the SSD was determined from reflection characteristics visible from profiles that were interpreted by means of the GeoSuite ${ }^{\circledR}$ software and calibrated with the vibrocorer data.

More than $100 \mathrm{~km}$ of high-resolution, single-channel seismic profiles were collected in the investigated shelf sector. The technical specifications and the methods of seismic data processing are described in De Falco et al. (2015).

The interpretation of seismic profiles is based on the seismic stratigraphic criteria of Mitchum et al. (1977) and is mostly in accordance with former interpretations reported in the literature on the regional geology (Fais et al., 1996; Lecca, 2000; Casula et al., 2001; Conforti et al., 2016). The seismic data analysis and the stratigraphic features of the study site have been described in De Falco et al. (2015) and Conforti et al. (2016). 


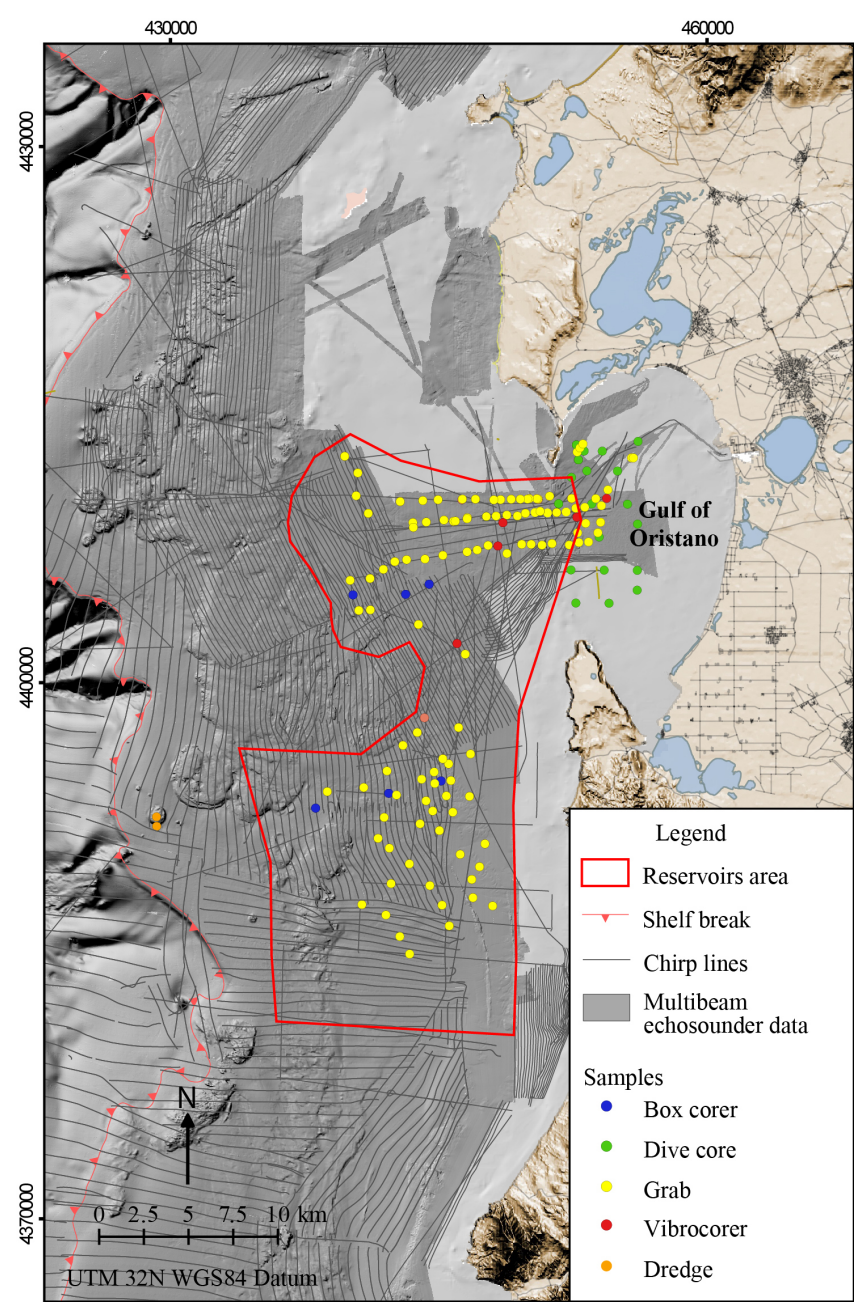

Figure 2. Locations of acquired data sets.

The maps of seismic facies boundaries have been used as key beds to define the lower limit of sand reservoirs, called the sand base (Fig. 4). The sand base is the unconformity which separates the transgressive sands deposited during the Holocene from the underlying Pleistocene sediments or Miocene-to-Pliocene bedrock.

The shape of the sand base surface was obtained by interpolating the depth values (referred to the present sea level) of the surface, from each seismic lines, in order to obtain the digital terrain model's $10 \mathrm{~m}$ cell size of the bottom of sand deposits.

The conversion of two-way travel time to real depth was obtained by assuming an average velocity of about $1550 \mathrm{~ms}$ within the first $300 \mathrm{~ms}$ of the seismic record below the sea floor (Carlson et al., 1986; Budillon et al., 2011). The vertical resolution of seismic data is $0.1 \mathrm{~m}$.

\subsection{Sedimentological data}

Sediment samples collected during the oceanographic cruises (Fig. 2) cited above were used to characterise the sandy sedimentary deposits. All 149 superficial sediment samples were collected with a Van Veen grab and a Box Corer, whereas five sediment cores up to $3 \mathrm{~m}$ long were collected by using a vibrocorer (Fig. 2). In all samples, grainsize distribution was measured using dry sieving for the gravel/sand fraction between 4000 and $90 \mu \mathrm{m}$ at half-phi intervals. Multivariate statistical techniques were used to classify sediment samples into sedimentary facies (De Falco et al., 2015; Brambilla et al., 2016; De Muro et al., 2017). The statistical analysis of sediments data was performed by the software GRADISTAT (Blott and Pye, 2011). Sedimentological data provided the ground-truth observations used to classify the acoustic facies obtained by multibeam bathymetry and backscatter data.

\subsection{Thickness and volume computation}

The model of the thickness of the SSD was created with the GIS spatial analysis tools. The thickness was estimated by subtracting the elevation value of each cell of the DTM of the sand base surface from the corresponding cell of the DTM of the seabed obtained through MBES surveys. The latter DTM was increased from 2.5 to $10 \mathrm{~m}$ cell size. The volumes were estimated from the digital map of the thickness of each deposit (Fig. 5) (Correggiari et al., 2013, 2016; Trobec et al., 2018).

The recognised submerged sand deposits were classified into seven hierarchic categories based on the volume of each deposit as shown in Table 1. The margin of error of sediment volume estimation was based on the vertical resolution of the seismic data used for surface interpolation (i.e. $0,1 \mathrm{~m}$ ).

\section{Results}

\subsection{Seabed morphology}

The seabed features of the continental shelf of centralwestern Sardinia, including the distribution of rocky outcrops, sedimentary facies and seagrass meadows is shown in Fig. 6. The map was obtained integrating the geophysical and sedimentological data with the map of seagrass meadow of Sardinia (Ministry of Environment Land and Sea, 2002), realised in 2002 by the Italian Ministry of Environment Land and Sea.

The outcropping and rocky basement were recognised mainly in the shelf sector facing the Sinis Peninsula and the Gulf of Oristano down to $150 \mathrm{~m}$ in depth. About 40 volcanic cone mounds, subcircular in plain view (Fig. 6), were recognised on the high-resolution DTM in a sector of approx. $40 \times 20 \mathrm{~km}^{2}$ (Conforti et al., 2016).

Sedimentary basins fill the depressions of the bedrock along the inner shelf. The backscatter data indicate a sharp 


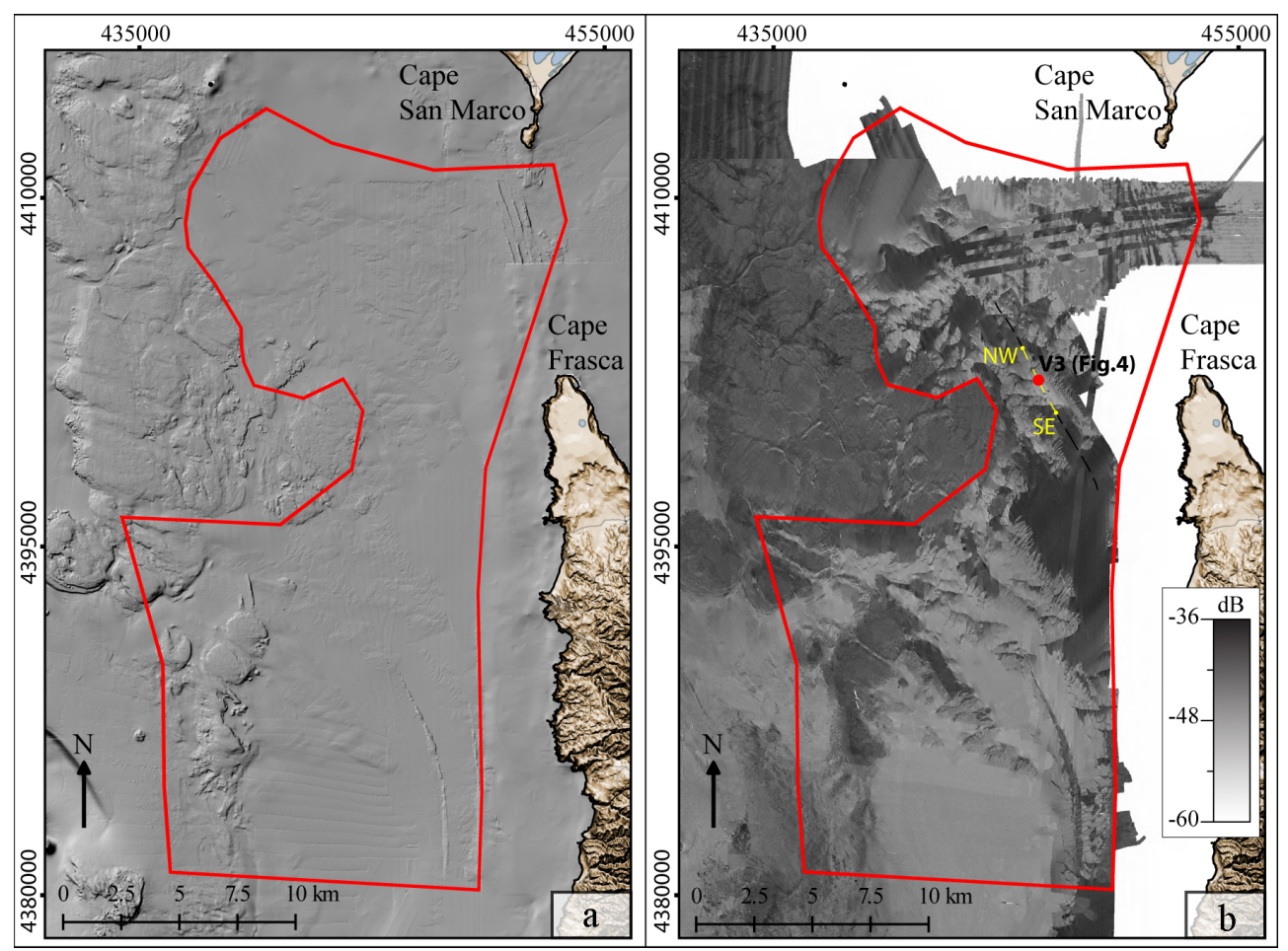

Figure 3. (a) Shaded relief map of a digital terrain model of the study sector; (b) distribution of relative backscatter intensity values of the same sector.
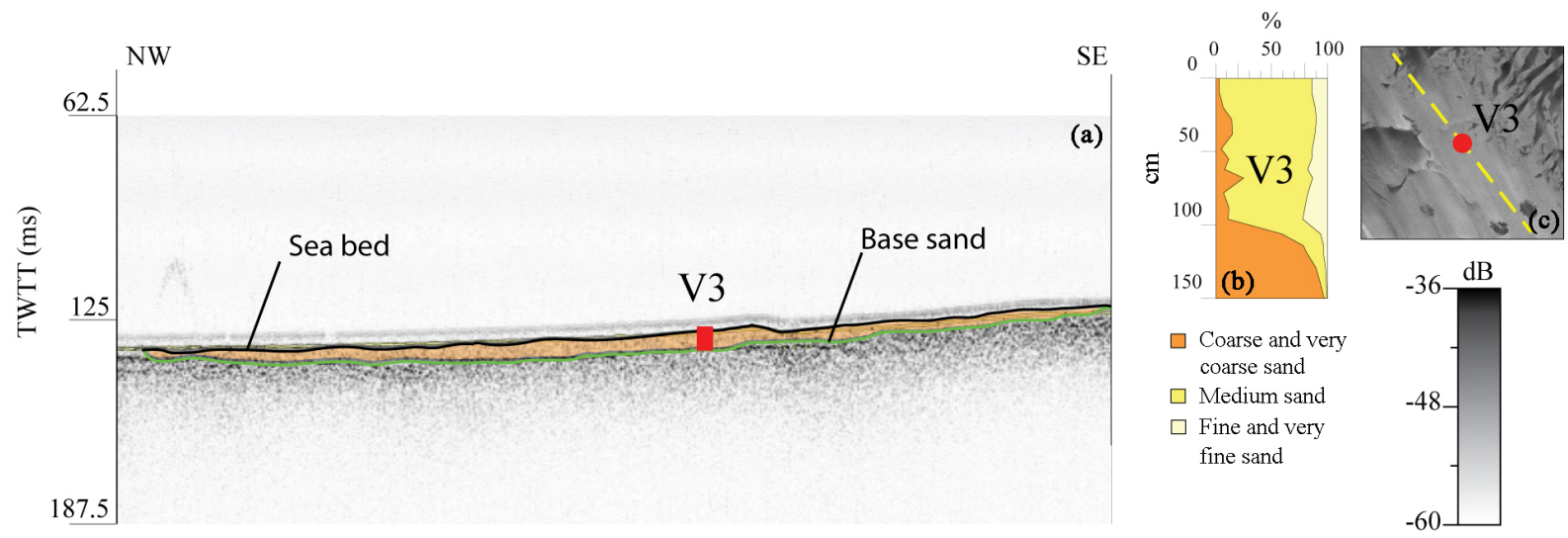

Figure 4. (a) Example of digitisation of the sand base in a chirp profile which is correlated with the core V3; (b) stratigraphic profile of the cores located on the chirp profile; (c) relative backscatter intensity value.

acoustic contrast of the sedimentary deposits along the basins. The sector reported in Fig. $1\left(150 \mathrm{~km}^{2}, 25\right.$ to $140 \mathrm{~m}$ in depth) was considered the more interesting for the analysis of SSD. Backscatter data, calibrated with sedimentary data, revealed an alternation of low and high backscatter values that reveal the presence of finer sediments alternating with coarse sediments: this sedimentary pattern is associated with the presence of sorted bedforms (De Falco et al., 2015). Lower backscatter values allowed us to identify the spatial limits of the finer sediments, which correspond to the transgressive sand layer deposit during the last sea level rise.

\subsection{Submerged sand deposit}

The features of sand deposits are shown in Table 1. The sedimentological analysis allowed us to characterise the study area and sand reservoirs. Four textural and compositional groups were recognised: (i) muddy sands $\left(\mathrm{CaCO}_{3}\right.$ $66 \pm 8 \%$ ), (ii) fine sands $\left(\mathrm{CaCO}_{3} 63 \pm 17 \%\right.$ ), (iii) medium sands $\left(\mathrm{CaCO}_{3} 43 \pm 29 \%\right)$ and (iv) sandy gravels $\left(\mathrm{CaCO}_{3}\right.$ 


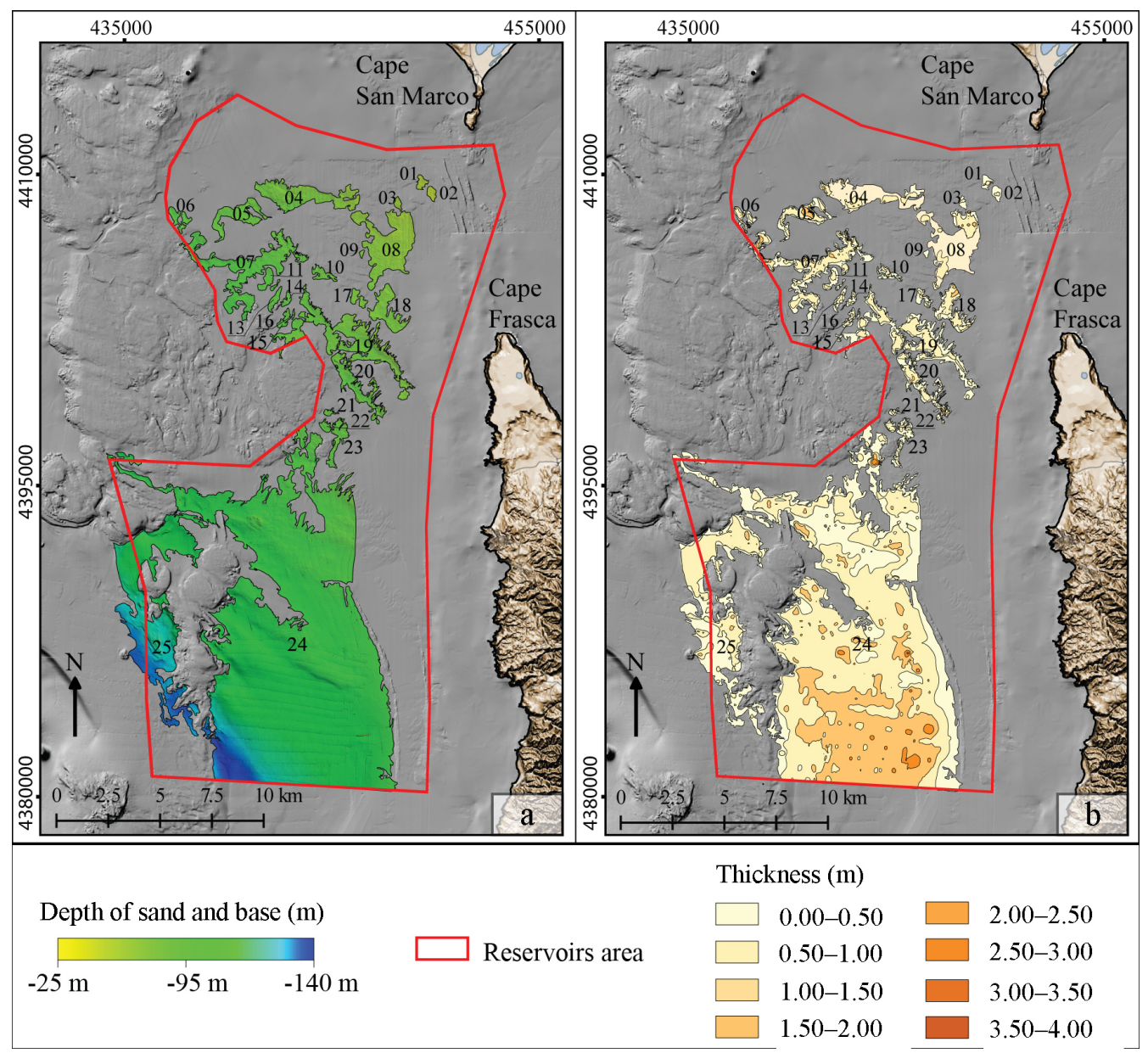

Figure 5. (a) Digital terrain model of the sand base; (b) thickness map of submerged sand deposits (SSDs).

$14 \pm 11 \%$ ) (see De Falco et al., 2015 for the sedimentary facies classification). This subdivision is also of a spatial nature, with the muddiest sediments located in the southernmost sector of the investigated area, the fine sands corresponding to the areas occupied by sorted bedforms and the medium sands located at the mouth of the Gulf of Oristano.

The muddy sands were not considered to be potential SSDs due to the high average mud content $(24 \pm 11 \%)$. Fine and medium sands were fully characterised because those deposits were sampled by vibrocorers. Consequently, the SSDs reported in this work are mixed fine and medium sand forms with available geophysical and sedimentological data.

The stratigraphy of mixed fine and medium sand shows the presence of a few metres of acoustically transparent sedimentary cover, superimposed on a thicker layer formed by sandy gravel.

Twenty-five mixed fine and medium sand deposits have been detected for a total surface of $148 \mathrm{~km}^{2}$ (Fig. 5). The thickness reaches $4 \mathrm{~m}$ but is mostly in the range of 1 to $2 \mathrm{~m}$. The total volume of the superficial sedimentary bodies has been estimated at $130000 \mathrm{Mm}^{3}$. An identification number (id_n) has been associated with each deposit (Table 1).

The deposits were classified into several categories to facilitate data management and description. Eight deposit categories (named Type $n$ ) are recognised based on the volume of the single deposit:

- Type 1 (volume $<0.001 \mathrm{Mm}^{3}$ ) consist of four deposits (id_01, id_02, id_03 and id_09) that have irrelevant volumes of less than $1000 \mathrm{~m}^{3}$ each and thicknesses between 0.5 and $1 \mathrm{~m}$. These small deposits, composed mainly of fine sand, have been mapped to complete the characterisation of SSDs in the studied area.

- Type 2 (volume $0.01<0.06 \mathrm{Mm}^{3}$ ) is composed of six deposits (id_04, id_08, id_12, id_14, id_16 and id_21), has a total volume of $0.166 \mathrm{Mm}^{3}$, corresponding to $0.1 \%$ of the total volume detected and has thickness $c$, and ranges from 0.50 to $2 \mathrm{~m}$. The deposits of this group cover an area of about $9.8 \mathrm{~km}^{2}$ and consist mainly of fine and medium-fine sand. 
Table 1. Submerged sand deposit features.

\begin{tabular}{|c|c|c|c|c|c|}
\hline Name_id & $\begin{array}{r}\text { Perimeter } \\
(\mathrm{km})\end{array}$ & $\begin{array}{r}\text { Surface } \\
\left(\mathrm{km}^{2}\right)\end{array}$ & $\begin{array}{l}\text { Volume } \\
\qquad\left(\mathrm{m}^{3}\right)\end{array}$ & $\begin{array}{l}\text { Sand class (Folk and } \\
\text { Ward, 1957) }\end{array}$ & Type \\
\hline 01 & 2.7 & 0.24 & $<1 \times 10^{3} \pm 100$ & Fine sand & 1 \\
\hline 02 & 2.0 & 0.22 & $<1 \times 10^{3} \pm 100$ & Fine sand & 1 \\
\hline 03 & 2.0 & 0.16 & $<1 \times 10^{3} \pm 100$ & Fine sand & 1 \\
\hline 04 & 2.2 & 3.95 & $3.7 \times 10^{3} \pm 370$ & Medium fine sand & 2 \\
\hline 05 & 13.0 & 1.88 & $1285 \times 10^{3} \pm 120000$ & Medium fine sand & 4 \\
\hline 06 & 6.5 & 0.54 & $312 \times 10^{3} \pm 30000$ & Medium fine sand & 3 \\
\hline 07 & 45.8 & 5.95 & $3600 \times 10^{3} \pm 360000$ & Medium fine sand & 5 \\
\hline 08 & 20.0 & 5.54 & $16 \times 10^{3} \pm 1600$ & Fine sand & 2 \\
\hline 09 & 1.0 & 0.05 & $<1 \times 10^{3} \pm 100$ & Fine sand & 1 \\
\hline 10 & 5.7 & 0.43 & $146 \times 10^{3} \pm 14000$ & Fine sand & 3 \\
\hline 11 & 3.5 & 0.41 & $161 \times 10^{3} \pm 16000$ & Fine sand & 3 \\
\hline 12 & 1.8 & 0.07 & $13 \times 10^{3} \pm 1300$ & Fine sand & 2 \\
\hline 13 & 3.5 & 0.32 & $115 \times 10^{3} \pm 11500$ & Fine sand & 3 \\
\hline 14 & 2.7 & 0.19 & $56 \times 10^{3} \pm 5500$ & Fine sand & 2 \\
\hline 15 & 3.6 & 0.27 & $110 \times 10^{3} \pm 11000$ & Fine sand & 3 \\
\hline 16 & 1.2 & 0.04 & $7.6 \times 10^{3} \pm 760$ & Fine sand & 2 \\
\hline 17 & 4.1 & 0.37 & $115 \times 10^{3} \pm 11500$ & Fine sand & 3 \\
\hline 18 & 12.1 & 1.83 & $1118 \times 10^{3} \pm 111000$ & Fine sand & 4 \\
\hline 19 & 65.5 & 6.53 & $3003 \times 10^{3} \pm 300000$ & Fine sand & 5 \\
\hline 20 & 29.1 & 2.12 & $1021 \times 10^{3} \pm 10000$ & Fine sand & 4 \\
\hline 21 & 2.6 & 0.13 & $36 \times 10^{3} \pm 3600$ & Fine sand & 2 \\
\hline 22 & 2.5 & 0.21 & $127 \times 10^{3} \pm 12000$ & Fine sand & 3 \\
\hline 23 & 11.0 & 0.96 & $322 \times 10^{3} \pm 30000$ & Fine sand & 3 \\
\hline 24 & 165.3 & 103.35 & $11038 \times 10^{3} \pm 1104000$ & Fine/very fine sand & 7 \\
\hline 25 & 72.5 & 16.32 & $8471 \times 10^{3} \pm 800000$ & Fine/very fine sand & 6 \\
\hline
\end{tabular}

- Type 3 (volume $0.10<0.35 \mathrm{Mm}^{3}$ ) consists of eight deposits (id_6, id_10, id_11, id_13, id_15, id_17, id_22 and id 23) that contain 0.11 to $0.32 \mathrm{Mm}^{3}$ each, for a total of $1.41 \mathrm{Mm}^{3}$. They cover an area of about $3.6 \mathrm{~km}^{2}$ and range from very fine to medium sand textural groups.

- Type $4\left(1.000<1.300 \mathrm{Mm}^{3}\right)$ consists of three deposits (id_05, id_18 and id_20) made up of over $1 \mathrm{Mm}^{3}$ each, for a total of $3424 \mathrm{Mm}^{3}$. They have a total surface of $6.6 \mathrm{~km}^{2}$ and are characterised by thicknesses ranging from 0.50 to $3 \mathrm{~m}$. These deposits are characterised by fine sands.

- Type $5\left(3.00<4.00 \mathrm{Mm}^{3}\right)$ consists of two deposits. The first (id_07) from $3.6 \mathrm{Mm}^{3}$ and the second from $3 \mathrm{Mm}^{3}$ (Id_19). The two deposits are developed for about $14.6 \mathrm{~km}^{2}$ and are characterised by thicknesses ranging from 0.5 to $3 \mathrm{~m}$, consisting of fine and mediumfine sands.

- Type 6 is represented by a single deposit (id_25) of $8.5 \mathrm{Mm}^{3}$, spread over an area of $16.8 \mathrm{~km}^{2}$. The thickness of this deposit varies from 0.5 to $2 \mathrm{~m}$. The weaving class of sands from fine to very fine.
- Type $7\left(>100 \mathrm{Mm}^{3}\right)$ is represented by the biggest single deposit (id_24), which, with its $110 \mathrm{Mm}^{3}$, represents $85 \%$ of the total volume measured. It covers an area of $104 \mathrm{~km}^{2}$ and the thickness varies from 0.5 to $4 \mathrm{~m}$. The sands of this deposit belong to the fine and very fine dimensional classes.

\section{Data availability}

The data set described in this study is publicly available and free of charge from the PANGAEA data repository (Brambilla et al., 2018). The data set presented is from WGS 84 / UTM zone $32 \mathrm{~N}$ and is composed of all data needed to characterise the SSDs, as well as the SSD features themselves.

\section{Discussion and conclusion}

Decision makers who face managing SSDs need knowledge that can be derived from a complex data set of geophysical and sedimentological data: in this work, we provided an example of organisation of such knowledge, collected and delivered in a useful online fashion. A wide portion of the continental shelf of Western Sardinian margin has been investi- 


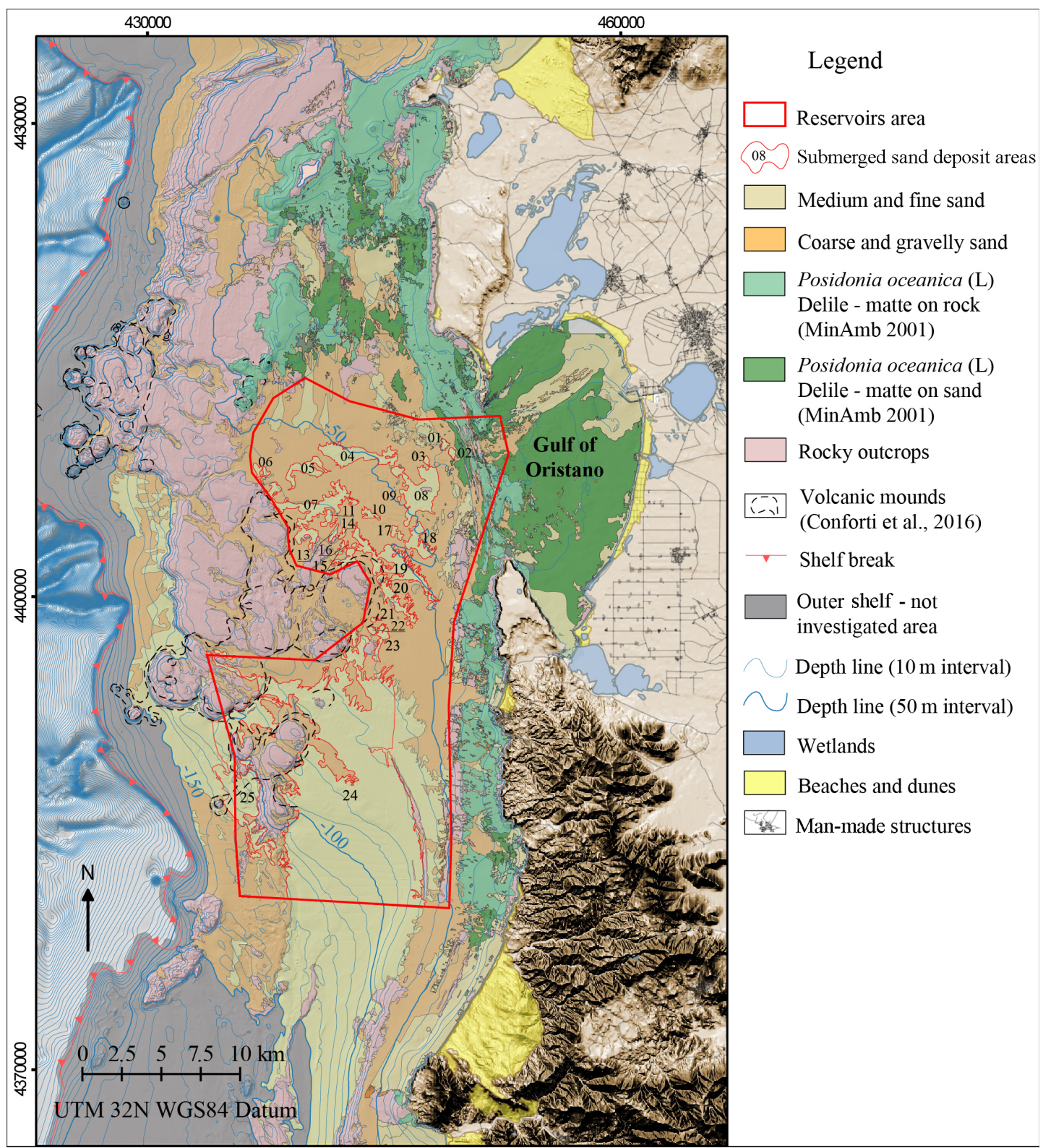

Figure 6. Map of seabed features of the continental shelf of central-western Sardinia.

gated. Along this area, several SSDs were detected and characterised in terms of grain size, stratigraphy, composition and available volume.

This deposition area of SSDs is located in a small structural basin limited by a rocky outcrop and mainly formed by volcanic mounds from the early Pliocene (Conforti et al., 2016 and reference therein).

The mixed fine and medium sands derive from the mixing and winnowing of siliciclastic riverine sediments (De Falco et al., 2015) with bioclastic sediments derived from marine benthic ecosystems (Posidonia oceanica and coralligenous assemblages) (De Falco et al., 2017). The fine and medium sand deposits are associated with submerged depositional ter- races characterised by a distinct clinoform pattern and were considered as transgressive deposits related to the last sea level rise (Carboni et al., 1989; De Falco et al., 2015).

The compatibility of SSDs with beach sediment of the adjacent coastal area is limited to a few sectors due to the great heterogeneity of beach sediment grain size and composition (De Falco et al., 2017, 2014, 2003). In particular, beaches located along the coast, ranging from the northern sector of the Gulf of Oristano to Cape Mannu, generally show a mixed composition with variable percentages of biogenic carbonate sediments. Some of these beaches are characterised by fine and medium sand grains, which are fully compatible with the identified SSDs. 
This low degree of similarity can be attributed to the different processes which sorted beach and offshore sediments: the former is characterised by extremely variable composition and grain size (De Falco et al., 2003) due to specific local conditions (coastal morphology and geology, nearshore carbonate factories) which enhance strong coastal compartmentalisation (Sanderson and Eliot, 1999); the latter were probably selected under similar conditions driven by shelf hydrodynamics.

In addition, the evaluation of similarity must take into account other parameters (e.g. sediment colour, grain roundness, mineralogy) that we do not evaluate in this work. Those sediment features are particularly important for pristine coastal sectors, such as the Western Sardinia coast, where the specific beach sediment typology is a fundamental component of the coastal landscape.

The future policy of coastal area and the marine spatial plans will be driven by the expected sea level rise (Finkl and Khalil, 2005; Armstrong et al., 2015; Barbanti et al., 2015; Brown et al., 2016), which will strongly influence the measures of protection against coastal flooding (Marchand et al., 2011; Mcglade et al., 2017).

Furthermore, as recommended by several projects funded by the European Union Commission (EUROSION; Conscience, Micore), the recognition and classification of strategic sediment reservoirs that can be used as a sediment supply for mitigation measures to contrast climate change are the basic concepts of coastal erosion management (Marchand et al., 2011).

In this context, knowledge of the location and characterisation of SSDs will be fundamental for planning the sand reservoir exploitation, which is used to plan coastal nourishment as protection against flooding.

This operation had to take into account the possible negative impact on the marine ecosystems and characterisation and monitoring studies before, during and after the dredging. The sediment handling and nourishment activities should be recommended to evaluate and minimise the potential impacts of these operations on the marine environment. For these reasons and to guarantee sustainable and long-term exploitation of non-renewable resource of SSDs, it is important to introduce the management of instruments focused on geological and physical characteristics of the sandy deposit, particularly those concerning the environmental data acquired for the management and monitoring of the exploitation of the submerged marine sand resource (Nicoletti et al., 2018).

Well-curated, federated sources of data set, organised in SDI, are strategic for providing a means to support exploitation strategies and the projects that provide use and monitoring of dredging, both during and after mining.

To conclude, this work summarises a large data set of geophysical and sedimentological data in order to map the spatial features of submerged sand deposits, which are useful for coastal management at present and in future climate change scenarios.
Author contributions. WB interpreted geophysical data, modelled the surfaces and thickness, mapped the seabed features, prepared the figures, wrote the manuscript and managed data and metadata handling on the online repository. AC acquired and processed the multibeam data set and the seismic profiles and managed data and metadata handling on the online repository. SS, acquired and processed the multibeam, seismic and sedimentological data in various campaigns and contributed in writing the manuscript. PC and SL developed the interoperable system based on the software suite Geoinformation Enabling Toolkit StarterKit ${ }^{\circledR}$ (GET-IT). GDF conceived and managed the study, processed data and contributed in writing the manuscript.

Competing interests. The authors declare that they have no conflict of interest.

Acknowledgements. The data of the present study were collected within the framework of the MAGIC project (Marine Geohazards along Italian Coasts) and the RITMARE project CNR (Subproject SP4, Work-Package 1, Actions 1,2). The interoperable system development activities have been funded by the RITMARE project. The authors are grateful to referees Jorge Guillen and Annamaria Correggiari for their helpful suggestions.

Review statement. This paper was edited by Kirsten Elger and reviewed by Annamaria Correggiari and Jorge Guillen.

\section{References}

Antonioli, F., Anzidei, M., Amorosi, A., Lo Presti, V., Mastronuzzi, G., Deiana, G., De Falco, G., Fontana, A., Fontolan, G., Lisco, S., Marsico, A., Moretti, M., Orrù, P. E., Sannino, G. M., Serpelloni, E., and Vecchio, A.: Sea-level rise and potential drowning of the Italian coastal plains: Flooding risk scenarios for 2100, Quaternary Sci. Rev., 158, 29-43, 2017.

Arisci, A., De Waele, J., Di Gregorio, F., Ferrucci, I., and Follesa, R.: Geoenvironmental analysis in coastal zone management: a case of study in Southwest-Sardinia (Italy), J. Coastal Res., 19, 963-970, 2003.

Armstrong, J., Wilby, R., and Nicholls, R. J.: Climate change adaptation frameworks: an evaluation of plans for coastal Suffolk, UK, Nat. Hazards Earth Syst. Sci., 15, 2511-2524, https://doi.org/10.5194/nhess-15-2511-2015, 2015.

Barbanti, A., Campostrini, P., Musco, F., Sarretta, A., and Gissi, E.: Developing a Maritime Spatial Plan for the Adriatic-Ionian Region, CNR-ISMAR, https://doi.org/10.5281/zenodo.48231, 2015.

Blott, S. J. and Pye, K.: GRADISTAT: A grain size distribution and statistics package for the analysis of unconsolidated sediments, Earth Surf. Proc. Land., 26, 1237-1248, https://doi.org/10.1002/esp.261, 2011.

Brambilla, W., van Rooijen, A., Simeone, S., Ibba, A., and De Muro, S.: Field observations, coastal video monitoring and numerical modeling at Poetto Beach, Italy, J. Coastal Res., 75, 825829, https://doi.org/10.2112/SI75-166.1, 2016. 
Brambilla, W., Conforti, A., Simeone, S., Carrara, P., Lanucara, S., and De Falco, G.: Submerged sand deposits data from Western Sardinia, Mediterranean Sea organised in an interoperable Spatial Data Infrastructure, PANGAEA, https://doi.org/10.1594/PANGAEA.895430, 2018.

Brown, J. M., Ciavola, P., Masselink, G., McCall, R., and Plater, A. J.: Preface: Monitoring and modelling to guide coastal adaptation to extreme storm events in a changing climate, Nat. Hazards Earth Syst. Sci., 16, 463-467, https://doi.org/10.5194/nhess-16463-2016, 2016.

Budillon, F., Conforti, A., Tonielli, R., De Falco, G., Di Martino, G., Innangi, S., and Marsella, E.: The Bulgheria canyon-fan A smallscale proximal system in the eastern Tyrrhenian Sea (Italy), Mar. Geophys. Res., 32, 83-97, 2011.

Carboni, S., Lecca, L., and Ferrara, C.: La discordanza versiliana sulla piattaforma occidentale della Sardegna, B. Soc. Geol. Ital., 108, 503-519, 1989.

Carlson, R. L., Gangi, A. F., and Snow, K. L. R.: Empirical reflection travel time versus depth and velocity versus depth functions for the deep sea sediments column, J. Geophys. Res., 91, 82498266, 1986.

Casula, G., Cherchi, A., Montadert, L., Murru, M., and Sarria, E.: The Cenozoic graben system of Sardinia (Italy): geodynamic evolution from new seismic and field data, Mar. Pet. Geol., 18, 863-888, https://doi.org/10.1016/S0264-8172(01)00023-X, 2001.

Church, J. A., Clark, P. U., Cazenave, A., Gregory, J. M., Jevrejeva, S., Levermann, A., Merrifield, M. A., Milne, G. A., Nerem, R. S., Nunn, P. D., Payne, A. J., Pfeffer, W. T., Stammer, D., and Unnikrishnan, A. S.: Sea level change, in: Climate Change 2013: the Physical Science Basis, Contribution of Working Group I to the Fifth Assessment Report of the Intergovernmental Panel on Climate Change, Cambridge University Press, Cambridge, UK and New York, NY, USA, 2013.

Ciavola, P., Ferreira, Ã., Haerens, P., van Koningsveld, M., Armaroli, C., and Lequeux, Q.: Storm impacts along European coastlines. Part 1: The joint effort of the MICORE and ConHaz Projects, Environ. Sci. Pol., 14, 912-923, https://doi.org/10.1016/j.envsci.2011.05.011, 2011.

Conforti, A., Budillon, F., Tonielli, R., and De Falco, G.: A newly discovered Pliocene volcanic field on the western Sardinia continental margin (western Mediterranean), Geo.-Mar. Lett., 36, 114, https://doi.org/10.1007/s00367-015-0428-0, 2016.

Correggiari, A., Perini, L., Foglini, F., Remia, A., Campiani, E., Calabrese, L., Luciani, P., Martini, A., Trincardi, F., and Pignone, R.: InSAND_Sistema_Informativo_Sabbie_Offshore_web online, available at: http://ambiente.regione.emiliaromagna.it/geologia/temi/costa/sistema-informativo-per-lagestione-dei-depositi-di-sabbia-sommersi (last access: 11 April 2019), 2012.

Correggiari, A., Remia, A., Foglini, F., Grande, V., Nicoletti, L., Perini, L., Piazza, R., and Bertaggia, R.: Research and exploitation of shelf marine sand deposit for coastal nourishment: geodatabase guidelines from northern Adriatic Shelf experience, SHAPE - Shaping an Holistic Approach to Protect the Adriatic Environment between coast and sea, IPA Project, Final meeting, 16-17 October 2013, Lignano, Italy, 2013.

Correggiari, A., Perini, L., Remia, A., Luciani, P., Foglini, F., Grande, V., Moscon, G., Calabrese, L., and Lorito, S.: Sis- tema Informativo per l'utilizzo della risorsa Sabbia offshore nei progetti di protezione costiera: geodatabase in_Sand, Servizio Geologico Sismico e dei Suoli, Regione Emilia Romagna, technical report, available at: https://ambiente.regione. emilia-romagna.it/it/geologia/temi/costa/pdf/in_sand_web.pdf (last access: 11 April 2019), 2016.

De Falco, G., Molinaroli, E., Baroli, M., and Bellacicco, S.: Grain size and compositional trends of sediments from Posidonia oceanica meadows to beach shore, Sardinia, Western Mediterranean, Estuar. Coast. Shelf S., 58, 299-309, 2003.

De Falco, G., Baroli, M., Cucco, A., and Simeone, S.: Intrabasinal conditions promoting the development of a biogenic carbonate sedimentary facies associated with the seagrass Posidoniaoceanica, Cont. Shelf Res., 28, 797-812, 2008.

De Falco, G., Tonielli, R., Di Martino, G., Innangi, S., Simeone, S., and Parnum, I. M.: Relationships between multibeam backscatter, sediment grain size, and Posidonia oceanica seagrass distribution, Cont. Shelf Res., 30, 1941-1950, 2010.

De Falco, G., Budillon, F., Conforti, A., De Muro, S., Di Martino, G., Innangi, S., Perilli, A., Tonielli, R., and Simeone, S.: Sandy beaches characterization and management of coastal erosion on western Sardinia island (Mediterranean sea), J. Coastal Res., 70, 395-400, 2014.

De Falco, G., Budillon, F., Conforti, A., Di Bitetto, A., Di Martino, G., Innangi, S., Simeone, S., and Tonielli R.: Sorted bedforms over transgressive deposits along the continental shelf of western Sardinia (Mediterranean Sea), Mar. Geol., 359, 75-88, 2015.

De Falco, G., Molinaroli, E., Conforti, A., Simeone, S., and Tonielli, R.: Biogenic sediments from coastal ecosystems to beach-dune systems: implications for the adaptation of mixed and carbonate beaches to future sea level rise, Biogeosciences, 14, 3191-3205, https://doi.org/10.5194/bg-14-3191-2017, 2017.

De Muro, S., Ibba, A., Simeone, S., Buosi, C., and Brambilla, W.: An integrated sea-land approach for mapping geomorphological and sedimentological features in an urban microtidal wave-dominated beach: a case study from S Sardinia, western Mediterranean, J. Maps, 13, 822-835, https://doi.org/10.1080/17445647.2017.1389309, 2017.

Desprez, M.: Physical and biological impact of marine aggregate extractionalong the French coast of the Eastern English Channel: short and long term post dredging restoration, ICES J. Mar. Sci., 57, 1428-1438, 2000.

Emery, K. O.: Relict sediments on continental shelves of the world, Am. Assoc. Petr. Geol. B., 52, 445-464, 1968.

Erftemeijer, P. L. A., Riegl, B., Hoeksema, B. W., and Todd, P. A.: Environmental impacts of dredging and other sediment disturbances on corals: a review, Mar. Pollut. Bull., 64, 1737-1765, 2012.

Eurosion: A guide to coastal erosion management practices in Europe, Eurosion project, 30 June 2004, available at: http://www. eurosion.org (last access: 11 April 2019), 2014.

Fais, S., Klingele, E. E., and Lecca, L.: Oligo-Miocene half graben structure in western Sardinian Shelf (western Mediterranean): reflection seismic and aeromagnetic data comparison, Mar. Geol., 133, 203-222, https://doi.org/10.1016/0025-3227(96)00030-8, 1996.

Finkl, C. W. and Khalil, S.: Offshore exploration for sand sources: General guidelines and procedural strategies along deltaic coasts, J. Coastal Res., 44, 203-233, 2005. 
Finkl, C. W. and Walker, H. J.: Beach Nourishment, Encyclopedia of Coastal Science, Encyclopedia of Earth Science Series, Springer, Dordrecht, the Netherlands, ISBN 978-1-4020-1903-6, 2005.

Folk, R. L. and Ward, W.: Brazos river bar: A study in the significance of grain size parameters, J. Sediment. Petrol., 27, 3-261, 1957.

Fraser, M. W., Short, J., Kendrick, G., McLean, D., Keesing, J., Byrne, M., Caley, J., Clarke, D., Davis, A. R., Erftemeijer, P. L. A., Field, S., Gustin-Craig, S., Huisman, J., Keough, M., Lavery, P. S., Masini, R., McMahon, K., Mengersen, K., Rasheed, M., Statton, J., Stoddart, J., and Wu, P.: Effects of dredging on critical ecological processes for marine invertebrates, seagrasses and macroalgae, and the potential for management with environmental windows using Western Australia as a case study, Ecol. Indic., 78, 229-242, https://doi.org/10.1016/j.ecolind.2017.03.026, 2017.

Fugazza, C., Oggioni, A., and Carrara, P.: RITMARE: Linked Open Data for Italian Marine Research", ERCIMNews, No. 96 (January 2014), 17-18, ISSN 0926-4981, available at: http://ercim-news.ercim.eu/en96/special/ ritmare-linked-open-data-for-italian-marine-research (last access: 11 April 2019), 2014.

Gault, J., O’Hagan, A. M., Cummins, V., Murphy, J., and Vial, T.: Erosion management in Inch beach, South West Ireland, Ocean Coast. Manage., 54, 930-942, 2011.

Grande, V., Proietti, R., Foglini, F., Remia, A., Correggiari, A., Paganelli, D., Targusi, M., Franceschini, G., La Valle, P., Berducci, M.T., La Porta, B., Lattanzi, L., Lisi, I., Maggi, C., Loia, M., Pazzini, A., Gabellini, M., and Nicoletti L.: Sistema Informativo per il monitoraggio ambientale della risorsa sabbia offshore nei progetti di protezione costiera: geodatabase Env_Sand. ISPRA, Manuali e Linee guida, 127/2015, 63 pp., ISBN 978-88-448-0742-9, available at: http://www.isprambiente.gov.it/files/pubblicazioni/ manuali-lineeguida/MLG_127_15_env_SAND.pdf (last access: 11 April 2019), 2015.

Horton, B. P., Rahmstorf, S., Engelhart, S. E., and Kemp, A. C.: Expert assessment of sea-level rise by AD 2100 and AD 2300, QuatSci. Rev., 84, 1-6, 2014.

Jiménez, J. A., Gracia, V., Valdemoro, H. I., Mendoza T., and Sánchez-Arcilla A.: Managing erosion-induced problems in NW Mediterranean urban beaches, Ocean Coast. Manage., 54, 907918, 2011

Khalil, S. M. and Finkl, C. W.: Spoil or Resource? Managing sediment for coastal restoration, J. Coastal Res., 64, Proceedings of the 11th International Coastal Symposium, Szczecin, Poland, 913 May 2011, 1433-1437, ISSN 0749-0208, 2011.

Kopp, R. E., Kemp, A. C., Bittermann, K., Horton, B. P., Donnelly, J. P., Gehrels, W. R., Hay, C. C., Mitrovica, J. X., Morrow, E. D., and Rahmstorf, S.: Temperature-driven global sea-level variability in the Common Era, P. Natl. Acad. Sci. USA, 15, 1434-1441, https://doi.org/10.1073/pnas.1517056113, 2016.

Lambeck, K., Antonioli, F., Anzidei, M., Ferranti, L., Leoni, G., Scicchitano, G., and Silenzi, S.: Sea level change along Italian coast during Holocene and a projection for the future, Quatern. Int., 232, 250-257, https://doi.org/10.1016/j.quaint.2010.04.026, 2011.
Lanucara, S., Oggioni, A., Modica, G., and Carrara, P.: Interoperable Sharing and Visualization of Geological Data and Instruments: A Proof of Concept, Computational Science and Its Applications - ICCSA 2017, Lecture Notes in Computer Science, 10407, https://doi.org/10.1007/978-3-319-62401-3_42, 2017.

Lecca, L.: La piattaforma continentale miocenico-quaternaria del margine occidentale sardo: blocco diagramma sezionato, Rendiconti Seminario Facoltà di Scienze Università di Cagliari, 70, 49-70, 2000.

Lecca, L., Carboni, S., Scarteddu, R., Sechi, F., Tilocca, G., and Pisano, S.: Schema stratigrafico della piattaforma continentale occidentale e meridionale della Sardegna, Memorie Società Geologica Italiana, 36, 31-40, 1986.

Marchand, M., Sanchez-Arcilla, A., Ferreira M., Gault, J., Jiménez, J. A., Markovic, M., Mulder, J., van Rijn, L., Stanic, A., Sulisz, W., and Sutherland, J.: Concepts and science for coastal erosion management an introduction to the CONSCIENCE framework, Ocean Coast. Manage., 54, 859-866, https://doi.org/10.1016/j.ocecoaman.2011.06.005, 2011.

MATTM-Regioni: Linee Guida per la Difesa della Costa dai fenomeni di Erosione e dagli effetti dei Cambiamenti climatici Versione 2018 - Documento elaborato dal Tavolo Nazionale sull'Erosione Costiera MATTM-Regioni con il coordinamento tecnico di ISPRA, 305 pp., 2018.

Mcglade, K., Barquet, K., Bogaard, T., Ciavola, P., van Dongeren, A., Ferreira, Ã., Higgins, R., Martinez, G., McCall, R., Stelljes, N., and Viavatenne, C.: Resilience-Increasing Strategies for Coasts - toolKIT (RISC-KIT), Synthesis Report, Middlesex University London, project report Risk-kit project, available at: http: //eprints.mdx.ac.uk/21860/ (last access: 11 April 2019), 2017.

Mengel, M., Levermann, A., Frieler, K., Robinson, L., Marzeion, B., and Winkelmann, R.: Future sea level rise constrained by observations and long-term commitment, P. Natl. Acad. Sci. USA, 113, 2597-2602, 2016.

Ministero Dell'Ambiente E Della Tutela Del Territorio: Mappatura delle praterie di Posidonia oceanica lungo le coste della Sardegna e delle piccole isole circostanti, Ministero dell'ambiente e tutela del territorio e del mare, Rome, Italy, 2002.

Mitchum Jr., R. M., Vail, P. R., and Sangree, J. B.: Seismic stratigraphy and global changes of sea level. Part 6. Stratigraphic interpretation of seismic reflection patterns in depositional sequences, AAPG Mem., 26, 117-133, 1977.

Nicoletti, L., La Valle, P., Paganelli, D., Lattanzi, L., La Porta, B., Targusi, M., Lisi, I., Loia, M., Maggi, C., Pazzini, A., Proietti, R., and Gabellini, M.: Aspetti ambientali del dragaggio di sabbie relitte a fini di ripascimento: protocollo di monitoraggio per l'area di dragaggio, ISPRA, Manuali e Linee Guida 72/2018, Istituto Superiore per la Protezione e la Ricerca Ambientale, Rome, Italy, 35 pp., 2018.

Pavesi, F., Basoni, A., Fugazza, C., Menegon, S., Oggioni, A., Pepe, M., Tagliolato, P., and Carrara, P.: EDI - A template-driven metadata editor for research data, Journal of Open Research Software, 4, e40, https://doi.org/10.5334/jors.106, 2016.

Pranzini, E.: Coastal erosion and shore protection: A brief historical analysis, J. Coast. Conserv., 22, 827-830, https://doi.org/10.1007/s11852-017-0521-9, 2018.

PueyoAnchuela, O., Frongia, P., Di Gregorio, F., CasasSainz, A., and Pocovì Juan, A.: Magnetometry and ground-penetrating radar surveys applied to tracing potential collectors of mining- 
derived pollutants in coastal sediments (Piscinas Bay, Montevecchio mining area, SW Sardinia), Environ. Earth Sci., 76, 230, https://doi.org/10.1007/s12665-017-6555-3, 2017.

Radermacher, M., Geerlof, W., de Schipper, M., Huisman, B., Aarninkhof, S., and Reniers, A.: Evolution of alongshore bathymetric variability around a mega-scale beach nourishment, in: Proceedings of Coastal Dynamics 2017, edited by: Aagaard, T., Deigaard, R., and Fuhrman, D., Helsingør, Denmark, 1370-1375, 2017.

Rahmstorf, S.: A semi-empirical approach to projecting future sealevel rise, Science, 315, 368-370, 2007.

Richards, J. A. and Nicholls, R. J.: Impacts of climate change in coastal systems in Europe. PESETA-Coastal Systems study, European Commission, Institute for Prospective Technological Studies, Joint Research Centre EUR 24130 EN, ISBN 978-9279-14627-5, https://doi.org/10.2791/3558, 2009.

Rogers, C. S.: Responses of coral reefs and reef organisms to sedimentation, Mar. Ecol. Prog. Ser., 62, 185-202, 1990.

Sage, F., Von Gronefeld, G., Déverchère, J., Gaullier, V., Maillard, A., and Gorini, C.: Seismic evidence for Messinian detrital deposits at the western Sardinia margin, northwestern Mediterranean, Mar. Petrol. Geol., 22, 757-773, 2005.

Sánchez-Arcilla, A., Jiménez, J. A., and Marchand, M.: Managing coastal evolution in a more sustainable manner. The Conscience approach, Ocean Coast. Manage., 54, 951-955, 2011.

Sanderson, P. G. and Eliot, I.: Compartmentalisation of beachface sediments along the southwestern coast of Australia, Mar. Geol., 162, 145-164, 1999.

Simeone, S. and De Falco, G.: Morphology and composition of beachcast Posidonia oceanica litter on beaches with different exposures, Geomorphology, 151-152, 224-233, 2012.
Simeone, S., De Falco, G., Quattrocchi, G., and Cucco., A.: Morphological changes of a Mediterranean beach over oneyear (San Giovanni di Sinis, western Mediterranean), J. Coastal Res., 70, 217-222, 2014.

Simeone, S., De Falco, G., Quattrocchi, G., Palombo, L., and Cucco, A.: Beaches morphological variability along a complex coastline (Sinis Peninsula, western Mediterranean Sea), J. Coastal Res., 75, 1302-1306, 2016.

Simeone, S., Molinaroli, E., Conforti, A., and De Falco, G.: Impact of ocean acidification on the carbonate sediment budget of a temperate mixed beach, Climatic Change, 150, 227-242, https://doi.org/10.1007/s10584-018-2282-3, 2018.

Tingy, V., Ozer, A., De Falco, G., Baroli, M., and Djenidi, S.: Relationship between the evolution of the shoreline and the Posidonia oceanica meadow limit in a Sardinian coastal zone, J. Coastal Res., 23, 787-793, 2007.

Trobec, A., Busetti, M., Zgur, F., Baradello, L., Babich, A., Cova, A., Gordini, E., Romeo, R., Tomini, I., Poglajen, S., Diviacco, P., and Vrabec, M.: Thickness of marine Holocene sediment in the Gulf of Trieste (northern Adriatic Sea), Earth Syst. Sci. Data, 10, 1077-1092, https://doi.org/10.5194/essd-10-1077-2018, 2018.

van Egmond, E. M., van Bodegom, P. M., Berg, M. P., Wijsman, J. W. M., Leewis, L., Janssen, G. M., and Aerts, R.: A mega-nourishment creates novel habitat for intertidal macroinvertebrates by enhancing habitat relief of the sandy beach, Estuar. Coast. Shelf S., 207, 232-241, https://doi.org/10.1016/j.ecss.2018.03.003, 2018.

Van Rijn, L. C.: Erosion of gravel/shingle beaches and barriers, EUProject CONSCIENCE, Deltares, Delft, the Netherlands, 2010. 